\title{
Global Art and Lost Regional Histories
}

\section{Ranjit Hoskote}

I

Despite the negative connotations it has carried, the periphery has historically often been a more dynamic theatre of development than the centre. Much of what we call classical Greek civilisation was achieved outside Greece, in the 'colonies' located in what are today western Turkey and southern Italy, where the Greek, Phoenician, Lydian, Persian and Indian lifeworlds intersected to produce new ways of crafting reality. Similarly, the nominally Indian religion of Buddhism reached its acme outside classical India's sophisticated metropolitan centres, in the Silk Route stations of Central Asia, where, too, a vibrant synthesis of cultural forms took place. Modernism, which we all suppose to have been the invention of the metropoles of Western Europe, was first given its name-modernismo - far away from these centres, on the cultural fringe of Nicaragua, by the poet Rubén Darío in 1888. I take heart from these demonstrations of the experimental energy of the periphery, which has too long been identified with provincialism and belatedness, too long been denied credit for being a laboratory of cultural possibilities.

I take heart, also, from Ian North's salutary reminder, offered during his magisterial interrogation of the falsified binary of centre and periphery, that 'good art can indeed be produced anywhere'. ${ }^{1}$ In the same spirit, I would argue that relevant ideas can indeed be produced anywhere, even if their influence is not felt immediately or globally because they have been produced in a part of the world that does not feature on the axis of the global art scene, or within a regional history or a language that has not been transmitted into the global archive of resources, citations and references. 
During the last decade, I have found it deeply problematic that, while art works from what we may designate as the Global South (formerly the Third World or postcolonial societies, but, to my mind, now including pockets and enclaves of dissidence and resistance within the former First World) travel beyond their sites of origin, the contexts from which they emerge and within which they have a primary and compelling meaning, do not similarly travel. Since 2000 , cultural productions from various regions in the Global South have been presented with increasing frequency by galleries, museums and biennials across the planet. But they become accepted, theorised and elaborated within a system of ideas that is still largely generated from the intellectual centres of Western Europe and Northern America (even if some of the intellectuals producing their critical positions from these centres belong to the Global South by descent).

Meanwhile, the intellectual sources that form or inform such art remain eclipsed: the exponents of such perspectives are not always members of the art world, or perhaps their work enjoys an oral circulation; the theatre of their debates may be conducted through private communication rather than public discourse; their writings may not been translated or, if written in global languages, may not have been published within the global circuit of art discourse. And, therefore, these contemporary regional formations of thought and opinion remain invisible, inaudible. In these circumstances, there is a very real danger of much art from the Global South being perceived as a set of generic outcomes prompted by a universally active globalisation, when, in truth, it is an array of cultural testimonies emerging from multiple regional modernities, each such modernity marking the specific and alternative response of a transitional society to the successive experiences of colonialism, internal discord over cultural and political direction, and globalisation. There is also the consequent danger that such art, while it makes new addresses to its new contexts, may lose some of the edge and power that it possesses in the ethos where it was first conceived and made.

I should make it clear that I do not have the modes of nostalgia, revanchism or nativism in mind when I speak of regional modernities or regional intellectual formations; 
far from it. I am speaking, rather, of autonomous claims to being-in-the-world and acting-in-the-world made in a variety of sites outside Western Europe and North America yet entangled with these zones of influence, and which Okwui Enwezor has described as the plural 'wills to globality' that inspire and prompt cultural production in the Global South. ${ }^{2}$ This is why I do not use that now outplayed adjective 'local'; to me, 'regional' encapsulates far more accurately the meld of local and global that increasingly constitutes the armature of place across our planet.

II

Speaking as an Indian-born cultural theorist and curator working transculturally, I would take India as a provisional case study, and cast this discussion in terms of a crisis of location. I believe that such a crisis challenges Indian artists today, after the demise of locality and its certitudes, and the onset of globalisation, conceived and experienced within the Indian art world as a universally executable program that inexorably overrides and transforms all regional mandates and preoccupations. In the context of Indian art and cultural production more generally - and at the risk of appearing somewhat summary and schematic-I would like to dramatise the effect of such globalisation as an interplay between two structures of transformation: the first, a structure of opportunities; the second, a structure of deficits. Whether we are artists, critics, curators or theorists, we have all been drawn into this interplay.

Globalisation as a structure of opportunities has brought all of us unprecedented possibilities of travel, collaboration and exchange; support for production; new interlocutors and audiences, and patterns of reception; and venues both for practice, in the form of studios, galleries, museums and biennials, as well as for reflection on practice, such as workshops, laboratories, and residencies. This structure of opportunities has been underwritten by a shift (not always acknowledged by the beneficiaries) in geopolitical arrangements - from the Cold War scenario of cultural warfare conducted through the Third World by the USA and the USSR, to the various soft-power initiatives launched from the 1990 on onward by 
countries such as Japan, the Netherlands, South Korea, Australia and Germany, among many others. These soft-power initiatives have been mapped over the work of transnational foundations and organisations such as the Triangle Arts Trust, HIVOS, the Prince Claus Fund, the Goethe-Institut, the Japan Foundation and so forth.

On the other hand, globalisation has also manifested itself as a structure of deficits. The mythology of broken borders and imaginative flight-paths can sometimes imply a rejection of alternative positions developed within the context of late-colonial and postcolonial modernity, so that the value of postcoloniality as an adversarial position comes to be questioned, and the supersession of the Cold War cultural universe is translated as a rejection of choices made during the 1950 s and 1960s, as wrong moves or historical errors - but which, in fact, may bear and even reward revisiting during the contemporary crisis of location. In India, these acts of rejection have produced an extraordinary amnesia towards the foundational texts that have sustained the emergence of this transitional society: as figures lying embalmed in the mausoleum of official history, M. K. Gandhi, Rabindranath Tagore, Jawaharlal Nehru and B. R. Ambedkar no longer circulate in the Indian public sphere as the restless originators of richly provocative, passionately interrogative philosophical experiments with cultural selfhood, the politics of subaltern agency and intercultural communication.

I find myself asking whether it is possible to retrieve, from this lost history of India's regional modernity, the utopian ideas of cosmopolitanism and intercultural dialogue, both phrased as critiques of the nation-state and insular patriotism, that we find in the writings of Tagore (Nationalism, 1916) and Nehru (The Discovery of India, 1946), published as both these authors stood at the threshold of momentous global changes. In Tagore and in Nehru we find dynamic proposals for activating connections beyond the cultural space of a nation or a nation-state, with the emphasis on finding interlocutors with whom we may not share histories, but with whom we may share other a variety of affinities and urgencies.

Tagore and Nehru premised their visions on an evolving selfhood that was receptive to a plurality of experience and 
contexts, as against the fixity of identities, and yet remained anchored in specific political predicaments, such as the need to dismantle the perceived and palpable power asymmetries held over from the colonial epoch. The leitmotif of these ideas was not parochiality or a turning inward and away from the world, but a confident self-releasement or a turning outward to embrace the world.

Tagore's dream of a pan-Asian dialogue led him to bring together, through publications and assemblies, the contemporary themes and questions that exercised intellectuals and artists in India, China, Korea and Japan; his dream informed the curriculum as well as the architecture of his experimental university, Santiniketan. Nehru's concerns, likewise, led him to subscribe to the ideology of Afro-Asian solidarity as well as to support utopian modernism: in Nehruvian India, these choices were articulated, variously, through the establishment of the global Non-Aligned Movement, the commissioning of Le Corbusier to design the new city of Chandigarh and of Louis Kahn to design a new management institute in Baroda, and in the establishment of Triennale India in 1968, which staked the claim of the Global South to host large-scale exhibitions of international art.

III

Such ideas need urgently to be brought out of the mausoleum and the library, and to be put back in play. Without them, globalisation as a structure of opportunities merely becomes a structure of anxieties and chance encounters, marking a generic belonging to a global system but in reality merely confirming recruitment into the global culture industry. While Indian artists - or artists from any transitional society-are not ambassadors for their location, especially when they now operate confidently in a transcultural space, I would suggest they have a choice between such a complacent globalisation of recruitment and a more unstable globalisation of resistance, where globalisation recognises itself to be a contested and turbulent, not an inevitable and apocalyptically redeeming, condition. The structure of deficits has meant, for a number of Indian artists, an evacuation of political energy from cultural production and a pursuit of floating images and narratives 
that signal instead of wrestling with the existential challenges of the global present.

Can we, therefore, imagine the possibility of recovering a conceptual space between a superseded and limiting local, and an overwhelming and generic global? Could we invoke the trope of the retrieval of unfinished projects, alternative temporalities, unattained utopias, to suggest the historical outlines and possible cartography of this conceptual space? And what better setting in which to represent, argue and mediate the claims of regional modernities than the biennial, which is quintessentially the parliament of unhoused narratives, lost memories, travelling images and nascent ideas seeking fluid locations?

It seems to me that the biennial - as a self-recursive yet self-disruptive periodic platform, as a temporary museum and itinerant archive, as an assembly of nomads committed to their practice but also to larger communities of practice, as the ground where the global cultural contemporary is being coproduced by diverse contributors - is the optimal laboratory where such an adventure may be proposed.

We are all aware that the nomad, as the preferred figure for the cultural producer who works transculturally, is a problematic and problematised figure: nomads like ourselves are often accused of enjoying the privilege of travel while millions of anonymous migrants cross borders in fear and desperation. But the nomad remains an attractive figure nonetheless, for she or he can also be a secular pilgrim, phrasing his or her pilgrimage as a quest for themes and questions that allow for a releasement of self towards others, towards locations that invite empathetic engagement, and towards seemingly quixotic and tangential ideas whose reserve of relevance has not been exhausted.

\section{Notes}

1 Ian North, respondent in panel on 'Global Frames and Critical Ruptures in Contemporary Art', convened by Nikos Papastergiadis and Victoria Lynn, Adelaide Festival Artists’ Week, 26 February 2010.

2 O. Enwezor, The Black Box Documenta II-Platform 5/ Kassel, exhibition catalogue (Ostfildern-Ruit: Hatje Cantz, 2002), 47. 